\title{
Field Evaluation and Enzyme-Linked Immunosorbent Assay Detection of Potato Leaf Roll Virus, Potato Virus X and Potato Virus $\mathrm{Y}$ in Potato Germplasm
}

\author{
Romana Anjum ${ }^{1,2}$, M. Aslam Khan ${ }^{2}$, Kolawole Oluwaseun Olawale ${ }^{3}$ \& Raheel Baber $^{4}$ \\ ${ }^{1}$ United States-Pakistan Centre of Advanced Studies in Agriculture and Food Security, University of Agriculture, \\ Faisalabad, Pakistan \\ ${ }^{2}$ Department of Plant Pathology, University of Agriculture, Faisalabad, Pakistan \\ ${ }^{3}$ Plant Pathology Section, Cocoa Research Institute of Nigeria, Ibadan, Nigeria \\ ${ }^{4}$ National Agriculture Research Centre, Rawalpindi, Pakistan \\ Correspondence: Romana Anjum, Department of Plant Pathology, University of Agriculture, Faisalabad, Punjab, \\ Pakistan. Tel: 92-333-650-7605. E-mail: romana.anjum@uaf.edu.pk
}

Received: March 26, 2017

doi:10.5539/jas.v9n7p229

\author{
Accepted: May 21, $2017 \quad$ Online Published: June 15, 2017 \\ URL: https://doi.org/10.5539/jas.v9n7p229
}

\begin{abstract}
Polerovirus: potato leaf roll virus (PLRV), Potyvirus: potato virus Y (PVY) and Potexvirus: potato virus X (PVX) is more destructive and well distributed throughout the Pakistan. Incidence has been reported to be as high as $90 \%, 25 \%$, and $\geq 15 \%$, respectively in the potato growing regions. To find out the source of resistance, twenty-nine virus free potato varieties were grown under field conditions with good agricultural practices. The disease severity of PLRV, PVY and PVX was recorded to determine the level of resistance of the potato varieties according to the disease rating scale. Infectivity and biological assay of all twenty-nine varieties were done in green house on potato, Datura stramonium, Nicotiana glutinosa and Physalis floridana. Non-inoculated plants were served as control. Leaf samples from potato varieties were collected for serological detection of PLRV, PVY and PVX by Double antibody sandwich Enzyme-Linked Immunosorbent Assay (DAS-ELISA). Out of twenty nine varieties, none of the variety was resistant to PLRV although three varieties; Mirrato, 394021-120 and Orla were moderately resistant. Only FD 48-4 and TPS 9813 showed resistance to PVX and PVY. While FD 3-10, FD 9616 and FD 37-13 were moderately to PVX and PVY. Rest of the varieties was found susceptible to all three viruses.
\end{abstract}

\section{Keywords: PLRV, PVY, PVX, DAS-ELISA}

\section{Introduction}

Potato (Solanum tuberosum L.) is the world's third most important food crop and widely distributed (Bhaskar et al., 2010) due to its high production and good nutritional value. Several diseases hamper its production (Ahmed \& Bhutta, 1989). Among these most important and extensively widespread are the aphid-transmissible RNA viruses (Robert, 2000; Kogovsek et al., 2010), i.e. Polerovirus: potato leaf roll virus (PLRV), Potyvirus: potato virus Y (PVY) and non aphid-transmissible RNA virus (Adams et al., 2004) Potexvirus: potato virus X (PVX). Potato leaf roll virus is more destructive and well distributed throughout the Pakistan (Mughal et al., 1988). Its incidence has been reported to be as high as $90 \%$ in the producing regions (Bhutta \& Bhatti, 2002). PLRV is transmitted in a circulative, persistent and non-propagative manner by its most important vector aphid; Myzus persicae Sulz (Salazar, 2003). During the primary infection, the seed tubers are asymptomatic, but symptoms become visible at secondary stage (Chatzivassiliou, 2008). PLRV causes a prominent upright characteristic rolling, chlorosis or reddening, and roughness in the texture of potato plant leaves (Khurana, 2004). The PLRV infected plant remains stunted in growth producing reduced number and size of tubers (Nawres, 2013). On the other hand, PVY is a highly variable virus with new emerging strains $\mathrm{PVY}^{\mathrm{O}}, \mathrm{PVY}^{\mathrm{N}}, \mathrm{PVY}^{\mathrm{C}}, \mathrm{PVY}^{\mathrm{NTN}}, \mathrm{PVY}^{\mathrm{N}: \mathrm{O}}$, PVY $^{\mathrm{NW}}$ (Dabijev et al., 2005; Kerlan, 2009; Kostiw, 2011). PVY is transmitted mechanically and by aphid (Myzus persicae) in a non-persistent manner (Jones et al., 2009; Kerlan \& Moury, 2009). PVY disease losses are up to $25 \%$ (Mughal et al., 1988) but it can destroy whole crop if it occurs along with PVX (Loebensstein, 2009). Most prominent symptom is the 'leaf-drop streak' or necrosis along the veins of the underside of leaflets and leaf 
mosaic (Rania, 2013). Crumbling and drooping of lower leaves leads to the whole plant collapse with very small necrotic tubers production (Singh et al., 2008). However, PVX transmits mechanically (Ryu \& Hong, 2009) and its losses are $\geq 15 \%$. Symptoms of PVX infected plants are generally mild mosaic, interveinal mosaic, rugosity and sometimes top necrosis (Kerlan, 2009). Successful management of these diseases requires resistant varieties certified seed potato and vector management. Thus many breeders and plant pathologists have made concerted efforts through different approaches such as tissue culture, specific growth strategies for seed production and storage, seed potato certification programs on biological and serological indexing of different potato varieties to control PLRV, PVY and PVX. Unfortunately, the potato varieties are still often seen on field showing disease symptoms. Therefore searching for sources of natural resistance is paramount. In this study, evaluation of the local potato germplasm against PLRV, PVX and PVY through ELISA is proposed to identify natural resistance varieties among the germplasm available.

\section{Methods}

Twenty-nine varieties of virus free potato obtained from Potato Research Institute Sahiwal, Punjab, Pakistan, were evaluated for their resistance against PLRV, PVY and PVX. The potato varieties were grown under field conditions. The seedlings were raised in a soil incorporated with well-rotted farm yard manure at $30 \mathrm{t} / \mathrm{ha}$ and NPK 2:1:1 fertilizer consisting of 125-kg phosphorus (P), 250-kg nitrogen (N), and 125-kg potassium (K) per hectare. The potato varieties were grown in a randomized complete block design (CRBD). Disease severity of PLRV, PVY and PVX infected plants showing symptoms were determined by visual inspection. The disease severity was recorded to determine the level of resistance of the potato varieties according to the disease rating scale of Khan et al. (2006).

\subsection{Infectivity and Biological Assay}

Twenty-nine varieties grown under field conditions were also grown in green house for infectivity and biological assay. Young naturally infected ELISA tested tissue of the potato varieties showing primary symptoms of PLRV and PVY (Figure 1) were collected from the field-grown potatoes. Infected scions obtained from the diseased plants were grafted onto healthy potato seedlings growing in the screen house. Wedge-grafting was performed as suggested by Bos (1999). A slanting cut of $0.5-1 \mathrm{~cm}$ was made on both sides of the stem of infected plant, and then inverted cut was made on upper portion of the healthy plant in pot. Diseased stem of $0.5-1 \mathrm{~cm}$ oblique cut was inserted into the inverted cut. The graft sites were wrapped tightly with parafilm and covered with polyethylene bags. The plants were checked daily. After 3-4 days, the bags were removed. Non-inoculated plants served as negative control. Datura stramonium, Nicotiana glutinosa and Physalis floridana inoculated with PLRV and PVY respectively were the positive control.

Virus infected leaves showing symptom of PVX (Figure 1) and positively ELISA tested were collected from the field. PVX infected leaves were crushed in a pestle and mortar, in chilled $0.05 \mathrm{M}$ phosphate buffer of $\mathrm{pH} 7.6$ (normally used at $1 \mathrm{~g} / \mathrm{ml}$ ) and sieved to obtain sap-inoculum. Leaves of each plant were mechanically inoculated using carborundum powder as an abrasive. Non-inoculated plants (buffer-inoculum) served as negative control. One month after inoculation, plants were visually evaluated for virus symptoms. Inoculated plants were covered for 24 hours with plastic sheet. These plants were kept under observation for a month to observe the disease symptoms.
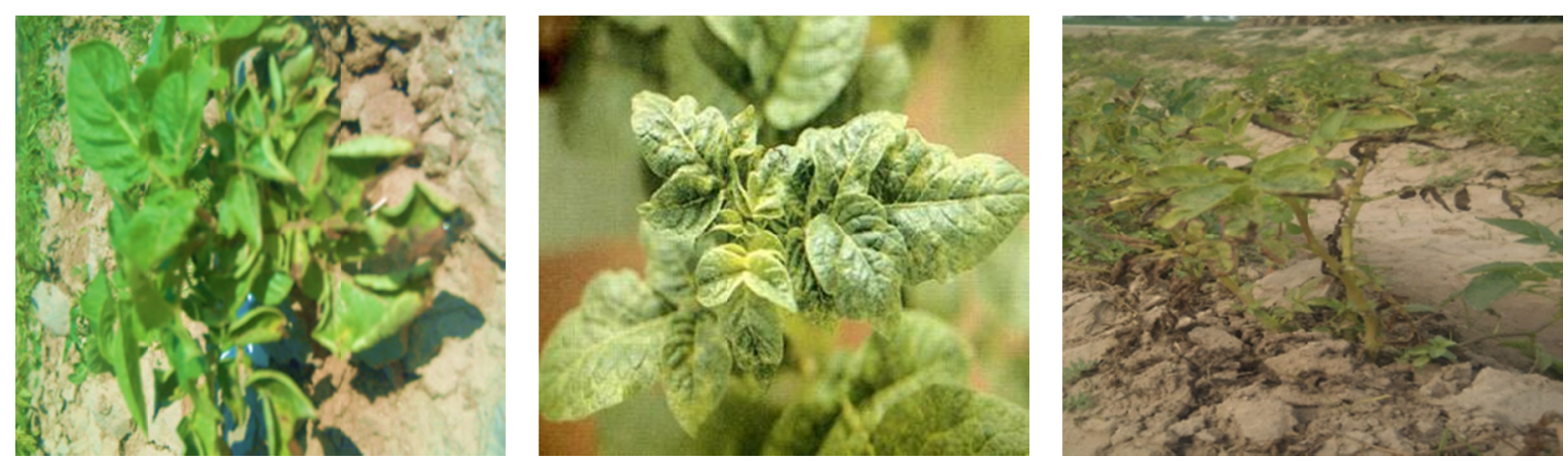

Figure 1. Symptoms of PLRV, PVX \& PVY 


\subsection{Serological Assay}

Leaf samples from potato varieties were collected for serological detection of PLRV, PVY and PVX. Double antibody sandwich Enzyme-Linked Immunosorbent Assay (DAS-ELISA) was used as described by Clark and Adams (1977). Antibody Coating Buffer (Distilled water 1 liter, Sodium carbonate $\left(\mathrm{Na}_{2} \mathrm{CO}_{3}\right) 1.59 \mathrm{~g}$, Sodium bicarbonate $\left(\mathrm{NaHCO}_{3}\right) 2.93 \mathrm{~g}$ ); Virus (Antigen) extraction Buffer (Sodium chloride $(\mathrm{NaCl}) 40 \mathrm{~g}$, Potassium Phosphate $\left(\mathrm{KH}_{2} \mathrm{PO}_{4}\right) 2 \mathrm{~g}$, Sodium phosphate $\left(\mathrm{Na}_{2} \mathrm{HPO}_{4}\right) 11.5 \mathrm{~g}$, Potassium chloride (KCl) $2 \mathrm{~g}$, Sodium azide $\left(\mathrm{NaN}_{3}\right) 2 \mathrm{~g}$, Polyvinyl pyrrolidone (PVP.MW. 4000) 2 g, Tween-20 (Polyoxyethylenesorbitan monolaurate) 0.5 $\mathrm{ml} / \mathrm{L}$, Egg-ova albumin $2 \mathrm{~g}$, Distilled water $800 \mathrm{ml})$; Washing Buffer $(5 \times$ PBS $200 \mathrm{ml}$, Distilled water $800 \mathrm{ml}$, Tween-20 $1 \mathrm{ml}$ ); Substrate Buffer (Diethanolamine $97 \mathrm{ml}$, Distilled water $800 \mathrm{ml}$ ); Enzyme Conjugate Buffer (Bovine serum albumin (BSA) $2 \mathrm{~g}$ and Polyvinylpyrrolidone (PVP) Mol. Wt. 40,000 $20 \mathrm{~g}$ ) were prepared by mixing and grinding with a mortar and pestle. Tissue samples were weighed into phosphate-buffered saline containing $0.5 \mathrm{ml} / \mathrm{L}$ Tween-20 (PBS-Tween) and $20 \mathrm{~g} / \mathrm{L}$ PVP and homogenized. Extracts usually were transferred immediately to the test plates. ELISA microtiter plates 96 wells were coated with PLRV, PVY and PVX antibodies (Agdia Company, Elkhart, USA) in three different microtiter plates, each diluted in coating buffer at 1:200. The coated plates were incubated at $4{ }^{\circ} \mathrm{C}$ for overnight. After incubation the plates were washed with PBS-Tween 3 times at 5 min intervals. These wells were filled with the sap of PLRV, PVY, and PVX infected tissue extracted in extraction buffer. Three and four wells filled with each of buffer and healthy samples, respectively. The plates were incubated for $4{ }^{\circ} \mathrm{C}$ and washed 3-4 times with PBST. Enzyme conjugate of $200 \mu 1$ was diluted at 1:200 and added. Incubated for overnight at $4{ }^{\circ} \mathrm{C}$ followed by washing 3-4 times with PBST. 200 $\mu \mathrm{l}$ of substrate buffer containing p-nitro phenyl phosphate $(75 \mu \mathrm{g} / \mathrm{ml})$ was freshly prepared and added to each well. Incubation at room temperature for 30 minutes was done and reaction for development of yellow colour was visually observed. The reaction was stopped by adding $50 \mu \mathrm{l} 3 \mathrm{M} \mathrm{NaOH}$ to each well. Colour intensity is proportional to the conc. of virus. Test results were scored visually as positive or negative based on the colour intensity of the reaction mixture.

In confirmation of the ELISA results, disease incidence data was observed as per internationally accepted disease rating scale (Table 1) for PLRV, PVX and PVY (Mughal \& Khan, 2001).

Table 1. Disease rating scale for PLRV, PVY \& PVX

\begin{tabular}{|c|c|c|}
\hline Disease Reaction (PLRV) & $\begin{array}{l}\text { Disease } \\
\text { severity index }\end{array}$ & $\begin{array}{l}\text { Reaction } \\
\text { (Level of resistance/susceptibility) }\end{array}$ \\
\hline No symptoms (Immune) & 0 & $\mathrm{I}(0 \%)$ \\
\hline $\begin{array}{l}\text { Rolling of upper leaves in case of primary infection and lower leaves in case } \\
\text { of secondary infection, erect growth (Resistant) }\end{array}$ & 1 & $\mathrm{R}(1-25 \%)$ \\
\hline $\begin{array}{l}\text { Rolling of leaves extending, leaves become stiff and leathery, stunting of plants } \\
\text { and erect growth (Moderately resistant) }\end{array}$ & 2 & $\operatorname{MR}(26-51 \%)$ \\
\hline $\begin{array}{l}\text { Short internodes, papery sound of leathery leaves, rolling and stunting of whole } \\
\text { plants Young buds are slightly yellowish and purplish (Moderately Susceptible) }\end{array}$ & 3 & MS (52-75\%) \\
\hline Clear rolling of leaves, severe stunting, few tubers, tuber necrosis (Susceptible) & 4 & $S(76-100 \%)$ \\
\hline Disease Reaction (PVY) & $\begin{array}{l}\text { Disease } \\
\text { severity index }\end{array}$ & $\begin{array}{l}\text { Reaction } \\
\text { (Level of resistance/susceptibility) }\end{array}$ \\
\hline No symptoms (Immune) & 0 & $\mathrm{I}(0 \%)$ \\
\hline (a) Blackening and banding of veins on few leaves & 1 & $\mathrm{R}(1-25 \%)$ \\
\hline \multicolumn{3}{|l|}{ (b) Mosaics started on all leaves (Resistant) } \\
\hline (a) Blackening and banding of veins on all leaves & 2 & $\operatorname{MR}(26-51 \%)$ \\
\hline \multicolumn{3}{|l|}{ (b) Narrowing of leaves (c) Venial necrosis sever mosaic } \\
\hline \multicolumn{3}{|l|}{ (d) Leaf crinkling (Moderately resistant) } \\
\hline Rugosity and leaf drop streak, dwarfing (Moderately Susceptible) & 3 & MS (52-75\%) \\
\hline Lower leaves dead, drooping, collapse of plants with very small tubers (Susceptible) & 4 & $\mathrm{~S}(76-100 \%)$ \\
\hline Disease Reaction (PVX) & $\begin{array}{l}\text { Disease } \\
\text { severity index }\end{array}$ & $\begin{array}{l}\text { Reaction } \\
\text { (Level of resistance/susceptibility) }\end{array}$ \\
\hline No symptoms (Immune) & 0 & I $(0 \%)$ \\
\hline Mild mottling on upper leaves (Resistant) & 1 & $\mathrm{R}(1-25 \%)$ \\
\hline Interveinal mosaic symptoms on more than one leaves (Moderately resistant) & 2 & $\operatorname{MR}(26-51 \%)$ \\
\hline Mosaic symptoms on all leaves (Moderately Susceptible) & 3 & MS (52-75\%) \\
\hline Distinct mosaic symptoms on all leaves with slight stunting and necrosis (Susceptible) & 4 & $\mathrm{~S}(76-100 \%)$ \\
\hline
\end{tabular}




\section{Results}

The twenty nine potato varieties tested against PLRV, PVY and PVX showed a range of symptoms from mild to severe mosaic and rugosity.

Among the twenty nine varieties, only FD 48-4 and TPS 9813 showed resistance to PVX. Although six of the varieties: FD 35-25, FD 3-10, FD 9616, FD 1-3, FD 37-13 and Mirrato were also moderately resistant. Thirteen of the varieties were moderately susceptible. These include FD 1-8, FD 32-2, TPS 9802, Desiree, FD 49-62, FSD Red, Astriex, 393574-61, TPS 9801, 394055-40, 394021-120, Safreen and Orla. However, the remaining varieties were very susceptible to PVX attack, including Cardinal, FSD White, FD 3-9, TPS 9803, 391202-158, 396240-21, Hermes and Oceania (Table 2).

Similar to the observed phenotype in PVX, FD 48-4 and TPS 9813 also showed resistance to PVY attack. Likewise, FD 3-10, FD 9616 and FD 37-13 are also moderately resistant to PVY attack, nonetheless, FD 3-9 and Oceania which are susceptible to PVX are moderately resistant to PVY. Two other varieties, 394055-40 and 394021-120 were also moderately resistant to PVY. Thirteen varieties which include FD 1-8, FD 32-2, TPS 9802, FD 1-3, FD 49-62, FSD Red, Astriex, 393574-61, 396240-21, TPS 9801, Mirrato, Safreen and Orla were moderately susceptible to PVY. Cardinal, FD 35-25, FSD White, Desiree, TPS 9803, 391202-158 and Hermes were very susceptible to PVY (Table 3).

Attack on the twenty nine potato varieties by PLRV was most severe of the three viruses. Notwithstanding, three of the varieties; Mirrato, 394021-120 and Orla were moderately resistant to PLRV. FD 48-4, FD 3-10, TPS 9802, FD 37-13, TPS 9813and Hermes were moderately susceptible. The remaining twenty one varieties were very susceptible to PLRV (Table 4).

ELISA reaction tested positive in all the twenty nine varieties tested against the three viruses. The test results were observed visually and recorded as positive or negative (Tables 2-4).

Table 2. Potato germplasm screening against PVX

\begin{tabular}{llll}
\hline Potato Varieties & Disease Rating & Level of Resistance & ELISA Reaction \\
\hline FD 48-4; TPS 9813 & 1 & $\mathrm{R}$ & $+\mathrm{ve}$ \\
FD 35-25; FD 3-10; FD 9616; FD 1-3; FD 37-13; Mirrato & 2 & $\mathrm{MR}$ & $+\mathrm{ve}$ \\
FD 1-8; FD 32-2; TPS 9802; Desiree; FD 49-62; FSD Red; Astriex; & 3 & $\mathrm{MS}$ & $+\mathrm{ve}$ \\
393574-61; TPS 9801; 394055-40; 394021-120; Safreen; Orla & & & $+\mathrm{ve}$ \\
$\begin{array}{l}\text { Cardinal; FSD White; FD 3-9; TPS 9803; 391202-158; } \\
\text { 396240-21; Hermes; Oceania }\end{array}$ & 4 & $\mathrm{~S}$ &
\end{tabular}

Note. (A) Level of resistance symbols: R: Resistant; MR: Moderately Resistant; MS: Moderately Susceptible; S: Susceptible; (B) ELISA reaction symbol: +ve: positive.

Table 3. Potato germplasm screening against PVY

\begin{tabular}{llll}
\hline Potato Varieties & Disease Rating & Level of Resistance & ELISA Reaction \\
\hline FD 48-4; TPS 9813 & 1 & $\mathrm{R}$ & $+\mathrm{ve}$ \\
FD 3-10; FD 9616; FD 3-9; FD 37-13; 394055-40; 394021-120; Oceania & 2 & $\mathrm{MR}$ & $+\mathrm{ve}$ \\
FD 1-8; FD 32-2; TPS 9802; FD 1-3; FD 49-62; FSD Red; Astriex; & 3 & $\mathrm{MS}$ & $+\mathrm{ve}$ \\
393574-61; 396240-21; TPS 9801; Mirrato; Safreen; Orla & & +ve \\
Cardinal; FD 35-25; FSD White; Desiree; TPS 9803; 391202-158; Hermes & 4 & $\mathrm{~S}$ & \\
\hline
\end{tabular}

Note. (A) Level of resistance symbols: R: Resistant; MR: Moderately Resistant; MS: Moderately Susceptible; S: Susceptible; (B) ELISA reaction symbol: +ve: positive. 
Table 4. Potato germplasm screening against PLRV

\begin{tabular}{llll}
\hline Potato Varieties & Disease Rating & Level of Resistance & ELISA Reaction \\
\hline Mirrato; 394021-120; Orla & 2 & MR & $+v e$ \\
FD 48-4; FD 3-10; TPS 9802; FD 37-13; TPS 9813; Hermes & 3 & MS & + ve \\
Cardinal; FD 1-8; FD 35-25; FSD White; FD 32-2; Desiree; FD 9616; & 4 & S & $+v e$ \\
FD 1-3; FD 49-62; FSD Red; FD 3-9; Astriex; 393574-61; TPS 9803; & & \\
391202-158; 396240-21; TPS 9801; 394055-40; Safreen; Oceania. & & & \\
\hline
\end{tabular}

Note. (A) Level of resistance symbols: R: Resistant; MR: Moderately Resistant; MS: Moderately Susceptible; S: Susceptible; (B) ELISA reaction symbol: +ve: positive.

\section{Discussion}

The field observation of the potato varieties showed that PVY, PVX and PLRV are very much distributed in the field. The widespread of these viruses has been reported previously (Jan \& Khan, 1995; Muhammad, 1990; Anwar \& Mirza, 1984). The presence of the potato viruses was detected through graft inoculation and mechanical transmission. These methods have been reported severally (Khan et al., 2002; Mayo et al., 2000; Muhammad, 1990; Mughal et al., 1988; Arif, 1988). The ELISA further corroborates the finding. Other studies have also shown the efficacy of ELISA in detecting viruses (Jarjees, 2000; Abou-Jawdah, 2001; Khan \& Saif, 2001; Abdullah, 1992). The potato varieties showed variable responses against the viruses. Hossain et al. (2002) also found similar responses to PLRV and PVY in different varieties. Most of the potato varieties evaluated in this experiment were moderately resistant and moderately susceptible. This pattern of resistant response was also observed for most potato varieties by Ahmad and Ahmad (1995). However, such type of varieties exhibiting tolerant responses have been found to be usually high yielding and might be a good source for the breeders to produce virus free seed through tissue culture techniques.

\section{Conclusion}

Further screening of potato germplasm is necessary for identification of resistant source.

\section{References}

Abdullah. (1992). Sattus of viral diseases of potato in Pakistan, their detection with ELISA technique. Proceeding workshop on Seed Potato Health, Islamabad (Vol. 19, pp. 34-42).

Abou-Jawadah, Y. (2001). Incidence of potato virus diseases and their significance for a seed certification program in Lebanon. Pytopathologia of Mediterranea, 40, 113-118.

Adams, M. J., Antoniw, J. F., Bar-Joseph, M., Brunt, A. A., Candresse, T., Foster, G. D., \& Fauquet, C. M. (2004). The new plant virus family Flexiviridae and assessment of molecular criteria for species demarcation. Archives of Virology, 149(8), 1045-1060. https://doi.org/10.1007/s00705-004-0304-0

Ahmad, \& Ahmad, W. (1995). Screening of potato germplasm for resistance against major potato viruses under field condition. Pakistan Jouranl of Phytopathology, 7(2), 177-183.

Ahmed, S. I., \& Bhutta, A. R. (1989). Major diseases of potato and their control. Progressive Farming, 9(3), 20-25.

Anwar, M. S., \& Mirza, M. S. (1984). Virus diseases of potato in the Punjab. Pakistan Journal of Agricultural Research, 22, 85-7.

Arif, M. (1988). Characterization of potato leaf roll virus (PLRV) (M.Sc. (Hons.) Thesis). Department of Plant Pathology, NWFP Agriculture University Peshawer.

Batool, A. (2006). Screening of potato germplasm against PLRV through ELISA and role of phenolic compounds in disease development (M.Sc. (Hons.) Thesis, p. 94). Department of Plant Pathology, University of Agriculture Faisalabad, Pakistan.

Bhaskar, P. B., Wu, L., Busse, J. S., Whitty, B. R., Hamernik, A. J., Jansky, S. H., \& Jiang, J. (2010). Suppression of the vacuolar invertase gene prevents cold-induced sweetening in Potato. Plant Physiology, American Society of Plant Biologists, 154, 939-948. https://doi.org/10.1104/pp.110.162545.

Bhutta, A. R., \& Bhatti, M. J. (2002). Seed potato certification in Pakistan (p. 66). FSCRD, Ministry of Food, Agriculture and Livestock, Islamabad, Pakistan. 
Bos, L. (1999). Plant viruses, unique and intriguing pathogen (p. 358). Backhuys Publishers Leiden, The Netherlands.

Chatzivassilioul, E. K., Moschos, E., Gazi, S., Koutretsis, P., \& Tsoukaki, M. (2008). Infection of potato crops and seeds with potato virus y and potato leaf roll virus in Greece. Journal of Plant Pathology, 90, 253-261. https://doi.org/10.4454/jpp.v90i2.660

Clark, M. F., \& Adams, A. N. (1977). Characteristics of micro plate method of enzyme linked immunosorbent assay for the detection of plant diseases. Journal of General Virology, 34, 475-483. https://doi.org/10.1099/ 0022-1317-34-3-475

Dabijev, J., Mihova, T., \& Muletarova, S. (2005). Investigation of the virus status of the potatoes in some regions producing high quality seed potatoes in Bulgaria. Biotechnology \& Biotechnological Equipment, 52-55. https://doi.org/10.1080/13102818.2005.10817262

Hossain, M., Ali, M. S., \& Rashid, M. M. (1994). Effect of inoculum levels of potato virus Y (PVY) on yield and subsequent spread of the disease under insecticide spray and unsprayed condition. Bangladesh Journal of Botany, 23-87.

Jan, H., \& Khan, S. B. (1995). Incidence and distribution of potato viruses in the upper Kaghan valley of Pakistan. Pakistan Journal of Phytopathology, 7, 13-6.

Jarjees, M. M. (2000). Application of enzyme-linked immunosorbent assay (ELISA) for rapid detecting of potato virus $\mathrm{Y}$ in Iraq. Arab Journal of Plant Protection, 18(1), 46-50.

Jones, R. A., Charkowski, A., Fribourg, C. E., Stevenson, W. R., \& Slack, S. A. (2009). Potato virus and virus-like diseases. Virus Diseases of Plants: Grape, Potato, and wheat image collection and teaching resource CD-Rom (pp. 1-102). American Phytopathological Society Press, St. Paul, MN, USA.

Kerlan, C. (2009). Potato viruses. In B. W. Mahy \& M. H. Van Regenmortel (Eds.), Desk encyclopedia of plant and fungal virology (Chap. 613, pp. 458-471). London: Elsevier Academic press, UK.

Kerlan, C., \& Moury, B. (2009). Potato virus Y. In B. W. Mahy \& M. H. Van Regenmortel (Eds.), Desk encyclopedia of plant and fungal virology (Chap. 613). London: Elsevier Academic Press, UK.

Khan, M. A., \& Saif-Ur-Rehman, M. (2002). Detection of major potato viruses from spring crop grown at three locations in the Punjab. Integrated plant disease management. Proceeding of $3^{\text {rd }}$ National Conference of Plant Pathology, NARC, Islamabad (pp. 113-115). Pakistan Phytopathpology Society.

Khan, M. A., Ahmad, W., \& Khan, S. M. (2002). Varietal screening against potato leaf roll virus based on serological assay. Pakistan Journal of Phytopathology, 14, 151-153.

Khan, M. A., Obaidullaha, U., \& Iqbal, J. (2006). Identification of resistant sources against potato leaf roll virus and M. persicae by biological tests and ELISA. Pakistan Journal Phytopathology, 8(2), 191-198.

Khurana, S. M. P. (2004). Potato Viruses and their Management. Diseases of Fruits and Vegetables, Diagnosis and Management, 1(2), 389-440. https://doi.org/10.1007/1-4020-2607-2_11

Kogovšek, P., Pompe-Novak, M., Baebler, Š., Rotter, A., Gow, L., Gruden, K. D., ... Ravnikar, M. (2010). Aggressive and mild Potato virus $\mathrm{Y}$ isolates trigger different specific responses in susceptible potato plants. Plant Pathology, 59, 1121-1132. https://doi.org/10.1111/j.1365-3059.2010.02340.x

Kostiw, M. (2011). The occurrence of major potato viruses in Poland. Journal of Plant Protection Research, 51, 204-209. https://doi.org/10.247/v10045-011-0035-7

Loebenstein, G. (2009). Plant virus diseases: Economic acpects. In B. W. Mahy \& M. H. Van Regenmortel (Eds.), Desk encyclopedia of plant and fungal virology (Chap. 613). London: Elsevier Acadamic press, UK.

Mayo, M., Rayboy, E., Farsey, G., \& Talianstry, M. (2000). Mechanical transmission of potato leaf roll virus. Journal General Virology, 81, 2791-2795. https://doi.org/10.1099/0022-1317-81-11-2791

Mughal, S. M., Khalid, S., Gillani, T. S., \& Devaux, A. (1988). Detection of potato viruses in Pakistan. Proceeding of $2^{\text {nd }}$ Triennial Conference, Kuming, China (pp. 189-90).

Mughal, S., \& Khan, M. A. (2001). Diseases rating scale for the assessment of disease severity of PVX and PVY to facilitate the researchers and students working on plant viruses for M.Sc. (Hons) Agriculture Thesis (p. 28). Department of Plant Pathology University of Agriculture, Faisalabad, Pakistan.

Muhammad, R. (1990). Studies on viral disease of potato crop in NWFP (M.Sc. (Hons.) Thesis). Department of Plant Pathology NWFP Agriculture University Peshawar. 
Nawres, A. S. A. (2013). Molecular characterization of viruses infecting potato and vegetables in Iraq (A Dissertation, p. 12). National Resource Institute, University of Greenwich, UK.

Prakash, A., Jagadiswari, R., \& Nandagopal, V. (2008). Future of Botanical Pesticides in rice, wheat, pulses and vegetables pest management. Journal of Biopesticides, 1, 154-169.

Rania, Z. A., Ibrahim, I. A. M., Hassan, H. M. S., \& El-Wakil, D. A. (2013). Incidence of virus Y strains and effect of infection on the productivity of potato tubers. IOSR Journal of Agricultural Veterinary Sciences, 2, 58-64. https://doi.org/10.9790/2380-0245864

Robert, Y. (2000). Some epidemiological approaches to the control of aphid-borne virus diseases in seed potato crops in northern Europe. Virus Research, 71, 33-47. https://doi.org/10.1016/S0168-1702(00)00186-6

Ryu, K. H., \& Hong, J. S. (2009). Potexvirus. In B. W. Mahy \& M. H. Van Regenmortel (Eds.), Desk encyclopedia of plant and fungal virology (Chap. 613, pp, 298-302). London: Elsevier Academic Press, UK.

Theoming, U. (2003). Potato Atlas and compendium of Pakistan (p. 33). Pakistan Agriculture Research Council, Islamabad, Pakistan.

\section{Copyrights}

Copyright for this article is retained by the author(s), with first publication rights granted to the journal.

This is an open-access article distributed under the terms and conditions of the Creative Commons Attribution license (http://creativecommons.org/licenses/by/4.0/). 